Valdis Dombrovskis

\title{
Eiropas un Latvijas ekonomiskās attīstības perspektīvas Covid-19 pēckrīzes periodā un Eiropas finansējuma sniegtās iespējas
}

Covid-19 pandēmija jau ir prasījusi 3,7 miljonu cilvēku dzīìibu visā pasaulē, oficiāli ir apstiprināti vairāk nekā 160 miljoni saslimšanas gadijumu. ${ }^{1}$ Pandēmija ir dziḷi satricinājusi pasaules un Eiropas ekonomisko un sociālo iekārtu. Tā ir uzrādījusi Eiropas Savienības (ES) vājās vietas, bet arī izcēlusi tai piemìtošās stiprās puses. Eiropas Savienībā pandēmija ir izraisījusi arī dziļu ekonomisko krīzi, ka arī saasinājusi sociālo un ekonomisko nevienlīdzību. Īstermiṇā, īstenojot apjomīgus atbalsta pasākumus, ir izdevies ierobežot ekonomikas kritumu un bezdarba pieaugumu. ${ }^{2}$ Tomēr joprojām ir cieši jāseko līdzi ekonomikas tendencēm, nepieciešamības gadījumā sniedzot atbalstu, lai izvairītos no daudzu uzṇēmumu maksātnespējas un attiecīgi augstāka bezdarba līmeṇa un lielākas sociālās nevienlīdzības gan Latvijā, gan Eiropā.

Pētījuma mērķis ir sniegt ieskatu, kā Covid-19 krīze ir ietekmējusi Eiropas un Latvijas ekonomiku, Eiropas Savienības istenotos atbildes pasākumus un to nodrošināšanai izveidoto finanšu ietvaru. Tāpat šajā publikācijā analizēts, kā Eiropas Savienības izveidotos finanšu instrumentus izmantot Latvijas tautsaimniecỉbas potenciāla kāpināšanai un konkurētspējas veicināšanai pēckrīzes periodā.

Covid-19 pandēmijas kopējo ietekmi uz pasaules, Eiropas un Latvijas ekonomiku šobrīd prognozēt vēl ir sarežğîti. To ietekmēs vairāku

1 WHO Coronavirus (COVID-19) Dashboard. Pieejams: https://covid19.who.int/ [skatitts 14.05.2021.]

2 Commission Communication. One year since the outbreak of COVID-19: fiscal policy response. Brussels, March, 2021. 
faktoru kopums - kā galvenos var minēt vakcinēšanas kampaṇu efektivitāti pandēmijas pārvarēšanā, valdību noteikto ierobežojumu atcelšanas vai atvieglošanas tempu un uzṇēmumu un mājsaimniecību reakciju uz tiem. Sākumā ìss ieskats par to, kā pasaules, Eiropas un Latvijas ekonomika ir reagéjusi uz Covid-19 krīzi līdz šim.

\section{Makroekonomiskā situācija krīzes ietekmē}

Par atskaites punktu var ņemt 2020. gada janvāri, kad parādījās pirmā informācija par jaunā Covid-19 vīrusa nopietnību K̦innas provincē Uhaṇā. Galvenie faktori, kas negatīivi ietekmēja pasaules ekonomiku, ir saistībā ar pandēmiju ieviestie ierobežojumi un lielā nenoteiktība. Šo faktoru ietekmes dēḷ cieta pirmām kārtām globālais patēriṇš, investīijas un tirdzniecība.

Saskañā ar Eiropas Komisijas 2021. gada pavasara ekonomisko prognozi ${ }^{3}$ pasaules IKP (izṇemot ES) 2020. gadā saruka par 2,9\%, bet 2021. gadā pieaugs par 5,9\%. Eiropas Savienības ekonomikā 2020. gadā bija 6,1\% kritums, bet 2021. gadā sagaidāms pieaugums par $4,2 \%$.

\section{1. attēls. 2021. gada pavasara ekonomiskā prognoze}

\begin{tabular}{|c|c|c|c|c|c|c|c|c|c|c|c|c|}
\hline & \multicolumn{7}{|c|}{ Rārskats - 2021. gada pavasara IKP pieaugums } & \multicolumn{7}{c|}{ Inflācija } \\
\hline & $\begin{array}{c}\text { 2021. gada pavasara } \\
\text { prognoze }\end{array}$ & \multicolumn{2}{c|}{$\begin{array}{c}\text { 2021. gada ziemas } \\
\text { prognoze }\end{array}$} & $\begin{array}{c}\text { 2021. gada pavasara } \\
\text { prognoze }\end{array}$ & $\begin{array}{c}\text { 2021. gada ziemas } \\
\text { prognoze }\end{array}$ \\
\hline & 2020 & 2021 & 2022 & 2020 & 2021 & 2022 & 2020 & 2021 & 2022 & 2020 & 2021 & 2022 \\
\hline Eirozona & $-6,6$ & 4,3 & 4,4 & $-6,8$ & 3,8 & 3,8 & 0,3 & 1,7 & 1,3 & 0,3 & 1,4 & 1,3 \\
\hline ES & $-6,1$ & 4,2 & 4,4 & $-6,3$ & 3,7 & 3,9 & 0,7 & 1,9 & 1,5 & 0,7 & 1,5 & 1,5 \\
\hline
\end{tabular}

Tiek prognozēts, ka Eiropas Savienības ekonomika pirmskrīzes līmeni sasniegs 2022. gada vidū. Tas ir agrāk, nekā tika prognozēts iepriekš, lielā mērā pateicoties apjomīgiem ekonomikas stimulēšanas pasākumiem. Tomēr ES dalībvalstīs izaugsmes tempi būtiski atšķirsies. Dažas dalībvalstis no pandēmijas ir cietušas vairāk, un tās ietekmi izjutīs ilgstošāk, īpaši tās, kuru ekonomika ir vairāk atkarīga no cietušiem sektoriem, piemēram, tūrisma. Tādējādi atsevišķas

\footnotetext{
3 European Economic Forecast. Spring 2021, Brussels, May, 2021.
} 
dalïbvalstis piedzīvos ekonomikas atgriešanos pirmspandēmijas līmenī jau 2021. gada beigās vai 2022. gada sākumā, bet citās šis process būs ilgāks.

Nākotnes prognozes ir saistītas ar pozitīiem un negatīviem faktoriem. Pie negatīviem faktoriem pieskaitāms apstāklis, ka 2020. gada rudenī epidemiolog̣iskā situācija Eiropā atkal pasliktinājās. Sākās pandēmijas otrais vilnis ar to saistītajiem ierobežojumiem, kam ir spēcīga negatīva ietekme uz ekonomiku. Vīrusa mutāciju dēḷ arī Eiropā ir sākuši izplatīties jauni, pēc epidemiologu vērtējuma arī daudz lipīgāki, vīrusa paveidi.

Pie pozitīviem faktoriem savukārt var minēt vakcīnu pieejamību agrāk, nekā bija paredzēts. 2020. gada pašā nogalē visās Eiropas Savienības dalībvalstīs tika sākta vakcinēšanas kampaṇa, kas ḷaus pakāpeniski samazināt vīrusa izplatību. Vēl 2020. gada vidū vakcīnu pieejamība tika prognozēta ne ātrāk kā 2021. gada pavasarī. Tomēr arī šeit jāņem vērā risks, ka vakcinēšanās kampaṇas var kavēties gan nepietiekama vakcinu apjoma dēl, gan problēmu dēḷ vakcinēšanas kampaṇu organizēšanā, gan zināmas daḷas iedzīvotāju nevēlēšanās vakcinēties dēḷ.

Vienlaikus pie pozitīviem faktoriem jāmin tas, ka Eiropas Savienības līmenī ir izdevies ātri vienoties par apjomīgiem ekonomikas stimulēšanas pasākumiem. Tas attiecas gan uz krīzes periodu, gan ekonomikas atlabšanas fāzi. 2020. gada jūlijā Eiropas Savienības Padome vienojās par ES nākamo daudzgadu budžetu un Eiropas ekonomikas atjaunošanas plānu - NextGenerationEU. Decembrī tika panākta arī politiskā vienošanās ar Eiropas Parlamentu. Minētie instrumenti rada stabilu finanšu ietvaru un ir svarīgs priekšnosacījums àtrai un sekmīgai krīzes pārvarēšanai.

Visbeidzot - 2020. gada decembrī Eiropas Komisija panāca vienošanos par turpmāko sadarbību starp Eiropas Savienību un Apvienoto Karalisti - ES un Apvienotās Karalistes Tirdzniecības un sadarbības nolīgumu, kas būtiski samazina ar Brexit saistīto negatīvo ietekmi uz ekonomiku.

\section{Ekonomiskā situācija Latvijā}

Covid-19 pandēmijas un noteikto ierobežojumu dēl 2020. gada otrajā ceturksnī Latvijas ekonomikas kritums bija gandrīz 9\% salīdzinājumā ar iepriekšējā gada attiecīgo periodu. Pēc ierobežojumu atvieglošanas gada otrajā pusē ekonomika strauji atkopās, un trešajā ceturksnī IKP kritums bija tikai 2,8\%, ceturtajā ceturksnī - 1,5\%. ${ }^{4}$ Kopumā 2020. gadā Latvijas ekonomikas kritums nebija tik

$4 \quad$ Centrālā statistikas pārvalde. Pieejams: www.csb.gov.lv 
2. attēls. Dalībvalstu IKP salīdzinājumā ar 2019. gada 4. ceturksni

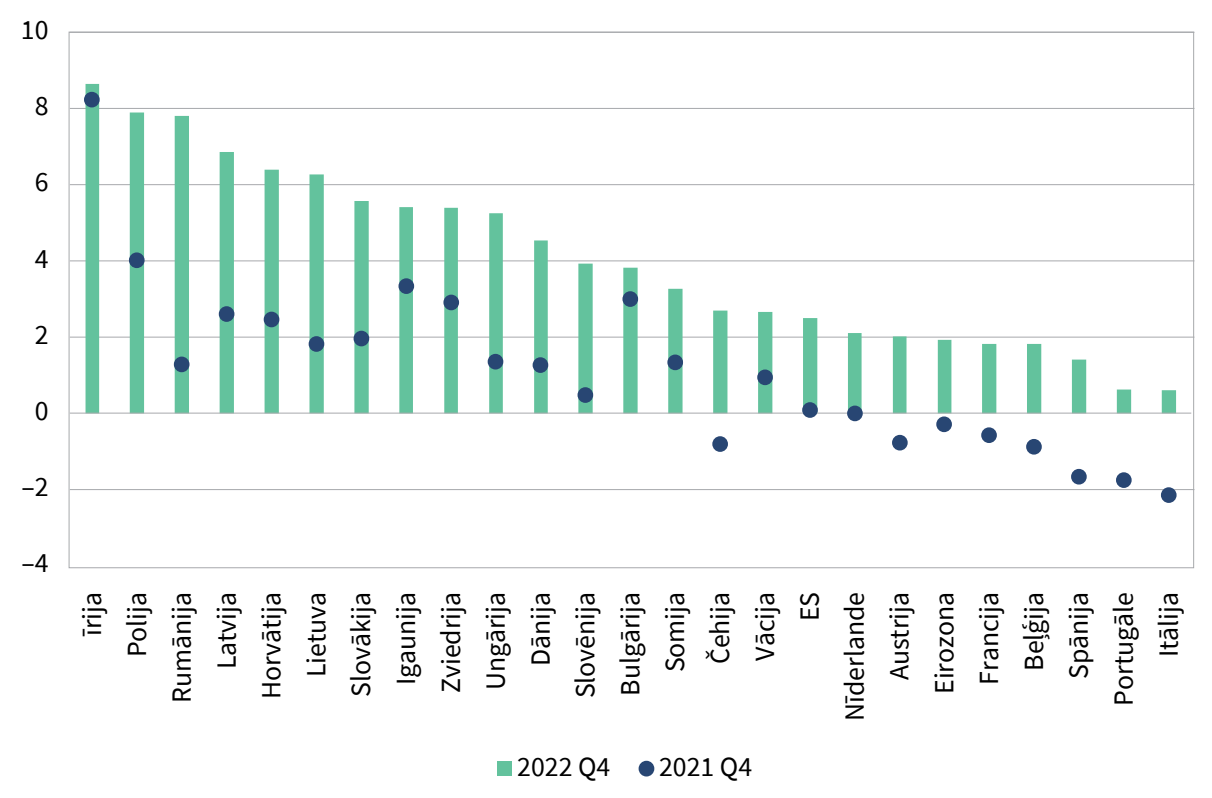

straujš, kā sākotnēji prognozēts - tikai 3,6\% salīdzinājumā ar rudenī prognozētajiem $5,5 \%{ }^{5}$ un pavasarī prognozētajiem $7 \%{ }^{6}$.

Tomēr saistībā ar pandēmijas otro vilni rudenī tika ieviesti stingrāki ierobežojumi, kuri nobremzēja ekonomikas atlabšanas procesu. Var prognozēt, ka, turpinoties ierobežojošajiem pasākumiem, 2021. gada pirmajā pusē ekonomikas atkopšanās joprojām būs lēna. Tomēr, ja valstī sāktā vakcinācijas kampaṇa noritēs atbilstoši plānam, ekonomikas atlabšanas process ievērojami paātrināsies gada otrajā pusē. Saskan̦ā ar Eiropas Komisijas 2021. gada pavasara ekonomisko prognozi 2021. gadā Latvijas IKP pieaugs par 3,5\%, kur galveno pienesumu dos privātā patēriṇa atkopšanās un eksports. Papildu stimulu ekonomikai sniegs Ekonomikas Atveseḷošanas un noturības mehānisma ietvaros paredzētais atbalsts.

2020. gadā privātais patēriņš un eksports saruka par attiecīgi 10,0\% un 2,7\%.7 Eksporta samazinājumu noteica milzīgs pakalpojumu eksporta kritums, bet preču eksports pat nedaudz pieauga. Arī investīiju sniegums bija ievērojami labāks, nekā sākotnēji prognozēts.

European Economic Forecast. Autumn 2020, Brussels, November, 2020.

6 European Economic Forecast. Spring 2020, Brussels, April, 2020.

7 Centrālā statistikas pārvalde. Pieejams: www.csb.gov.lv 
Vērtējot atsevišķas nozares, krīzes ietekme ir nevienmērīga, vairāk skarot, piemēram, tūrisma, viesmīlības, sabiedriskās ēdināšanas, transporta, jo īpaši aviotransporta, nozares. Būtiski ir cietušas arī kultūras un izklaides pasākumu jomas. Šìm nozarēm ir îpaši svarīga ierobežojumu ātrāka atcelšana un valsts atbalsts līdz tam.

Vienlaikus krīze vairākām nozarēm ir sniegusi straujākas izaugsmes iespējas. Ir būtiski pieaugusi digitālās ekonomikas loma: e-komercija, digitālā infrastruktūra un tiešsaistes platformas. Krīze ir paātrinājusi jau esošo tendenci, proti, digitālās ekonomikas, tirdzniecības un pakalpojumu attīstību.

Valsts budžeta izdevumi turpināja pieaugt, galvenokārt saistībā ar atbalsta pasākumiem pandēmijas pārvarēšanā. Vispārējā valdības budžeta izdevumi 2020. gadā pieauga par 12,1\% salīdzinājumā ar iepriekšējo gadu. Kopumā valdības lēmumi 2020. gadā nodrošināja tautsaimniecībai atbalstu 4,5\% apmērā no IKP, bet 2021. gadā tiek īstenoti vēl apjomīgāki ekonomikas stimulēšanas pasākumi. ${ }^{8}$

Nodarbinātības rādītāji uzrāda mazāku kritumu, nekā sākotnēji prognozēts. Arī tas lielā mērā ir saistīts ar valsts īstenotajiem nodarbinātỉbas un ienākumu atbalsta pasākumiem.

Kopumā Latvijas ekonomikas kritums 2020. gadā bija lēnāks nekā vidēji ES, bet straujāks nekā pārējās Baltijas valstīs (-0,9\% Lietuvā un $-2,9 \%$ Igaunijā). Tas, iespējams, ir saistîts ar mazāk dāsniem atbalsta pasākumiem un ekonomikas struktūras ietekmi. Piemēram, aviācijas nozares īpatsvars pārējo Baltijas valstu ekonomikā ir mazāks. Savukārt 2021. gadā Latvijas ekonomikai tiek prognozēta straujākā izaugsme starp Baltijas valstīm - Latvijā prognozēts 3,5\% IKP pieaugums, kamēr Igaunijā un Lietuvā attiecīgi 2,8\% un 2,9\% pieaugums. ${ }^{9}$

\section{Covid-19 krīzes salīdzinājums ar iepriekšējo krīzi}

Lai izvērtētu ES rīcību Covid-19 krīzes pārvarēšanā, nepieciešams izprast gan krīzes cēloṇus, gan to, kā reformas pēc iepriekšêjās krīzes ietekmēja Eiropas ekonomiskās un sociālās sistēmas noturību šobrīd.

2008. gada finanšu krīzes pirmsākumi meklējami ASV, un to noteica viegla lētu kredītu pieejamība, bezatbildīga kreditēšana, kas veicināja nekustamā īpašuma burbuḷa veidošanos, kā arī nepietiekama finanšu sektora uzraudzība.

"Lehman Brothers" bankas sabrukums 2008. gadā izraisija k̦ēdes reakciju un paniku finanšu tirgos, kas noveda pie pilnīgas kreditēšanas apstāšanās. ASV

8 Latvijas Stabilitātes programma 2021.-2024. gadam, Latvijas Republikas Finanšu ministrija, 2021. gada aprīlis.

$9 \quad$ European Economic Forecast. Spring 2021, Brussels, May, 2021. 
finanšu sektora sabrukums ieveda valsti un pēc tam arī visu pasaules ekonomiku dziḷā recesijā.

Globālās finanšu sistēmas ciešā savstarpējā sasaiste bija viens no galvenajiem krīzes ātrās izplatības iemesliem. Piemēram, Eiropas bankas, kas arī bija dzilii iesaistītas augsta riska hipotekārās kreditēšanas operācijās ASV, piedzīvoja tikpat smagus zaudējumus kā daudzas amerikāṇu bankas un bija galvenais kanāls krīzes pārnešanā uz Eiropu. Bankas abās Atlantijas okeāna pusēs izmantoja līdzīgus biznesa model̦us un piedzīvoja līdzīgas finansiālās problēmas, ko raksturoja nepietiekama kapitalizācija un likviditāte.

Finanšu krīzei sekoja valsts parāda krīze, kad vairākas eirozonas valstis Grieķija, Portugāle, İrija, Kipra un Spānija - bija spiestas meklēt starptautisko aizdevēju - citu eirozonas valstu, Starptautiskā Valūtas fonda un Eiropas Centrālās bankas - palīdzību.

Grieķijas un Portugāles valsts parāda ilgtspējas problēmas bija lielā mērā saistītas ar pirmskrīzes periodā īstenoto nelīdzsvaroto fiskālo politiku. Turpretī İrijas un Kipras krīzes cēlonis bija valsts finanšu sektora problēmas. Problemātisko banku rekapitalizācijas un restrukturizācijas izmaksas gūlās uz valsts pleciem, tādējādi l̦oti būtiski palielinot valsts budžeta deficītu un parādu. Spānijā minētās problēmas bija mazāk izteiktas, bet kombinējās ar nekustamā īpašuma burbuli.

\section{Krīžu salīdzinājums Latvijā}

Latvijā iepriekšējo krīzi izraisīja ārvalstu kredītu stimulēta ekonomikas pārkaršana. Globālās finanšu krīzes dēḷ apstājās finanšu plūsmas, plīsa nekustamā ipašuma burbulis, un Latvijas ekonomika piedzīvoja "smago piezemēšanos". "Parex" bankas problēmas un sekojošā nacionalizācija 2008. gada nogalē prasīja milzīgus budžeta līdzekḷus, un Latvija bija spiesta vērsties pēc ES un Starptautiskā Valūtas fonda aizdevuma. Papildu problēmas radīja spekulativie uzbrukumi latam. 2009. gadā Latvijas iekšzemes kopprodukts kritās par vairāk nekā 14\%, bet budžeta deficīts pat pēc apjomīgiem konsolidācijas pasākumiem sasniedza gandrīz $10 \%$ no IKP. ${ }^{10}$

Pašreizējais krīzes scenārijs būtiski atškiras no 2008. gada krīzes. Latvija Covid-19 krīzi sagaidīja eirozonas sastāvā un ar spēcīgiem ekonomikas pamatiem - sabalansētu ekonomisko izaugsmi, zemu budžeta deficītu un zemu tekošā konta deficitu.

Finansējuma pieejamība Latvijai kā eirozonas dalībvalstij ir izteikti labvēlīgāka nekā iepriekšējās krīzes laikā. Budžeta deficītu ir iespējams finansēt ar l,oti

10 Centrālā statistikas pārvalde. Pieejams: www.csb.gov.lv 
zemām procentu likmēm. Tādējādi, neraugoties uz būtisku ekonomiskās aktivitātes kritumu, spiediens uz Latvijas ekonomiku šobrīd ir daudz mazāks nekā 2008. gada krīzes laikā.

To labi ilustrē valdības izdevumu salīdzinājums abu krīžu laikā. 2008. gada beigās kḷuva skaidrs, ka valsts virzās pretī vēl nebijušai krīzei. Pēc "Parex" bankas nacionalizācijas Latvija zaudēja pieeju finanšu tirgiem ar visām no tā izrietošajām sekām. Valsts budžeta deficìtu bija iespējams finansēt tikai ar starptautisko aizdevēju palīdzību to noteiktajā apjomā.

Šajā krīzē situācija ir atšķirīga. 2020. gadā IKP kritums bija pietiekami nopietns, tomēr, pateicoties stabilam valsts finanšu stāvoklim, valsts joprojām spēj sekmīgi pildìt gan savas sociālās funkcijas, gan sildìt ekonomiku.

\section{Eiropas Savienības reakcija uz globālo finanšu un ekonomisko krīzi}

Viens no galvenajiem secinājumiem no globālās finanšu un ekonomiskās krīzes bija tāds, ka Eiropas Savienības institucionālā arhitektūra nav piemērota šāda veida krī̌u novēršanai un pārvarēšanai. Krīze atklāja arī būtiskas problēmas un neilgtspējīgas tendences daudzu Eiropas Savienības dalïbvalstu ekonomiskajās un fiskālajās politikās. Vienlaikus tā parādīja, cik lielā mērā savstarpēji atkarīgas ir Eiropas Savienības un it īpaši eirozonas valstu ekonomikas.

2008. gada krīze izraisīja būtiskas izmaiņas Eiropas ekonomikas pārvaldībā: tika būtiski nostiprināta ekonomiskās politikas koordinēšana, ieviešot Eiropas Semestri, tika stiprināta fiskālā disciplīna un uzraudzība, tika ieviestas jaunas procedūras makroekonomiskās nelīdzsvarotības novēršanai un pastiprināta finanšu nozares uzraudzība Eiropas Savienības līmenī.

Kā nozīmīgāko strukturālo reformu Eiropas Savienības līmenī var minēt 2011. gadā iedibināto Eiropas Semestri. Tā bija Eiropas Savienības atbilde uz finanšu un ekonomiskās krīzes laikā atklātajiem ekonomiskās pārvaldības trūkumiem.

Eiropas Semestra uzdevums ir stiprināt Eiropas fiskālo un makroekonomisko pārvaldību:

- nodrošināt ES dalībvalstu finanšu stabilitāti;

- novērst pārmērīgas makroekonomiskās nesabalansētības veidošanos ES dalībvalstīs;

- atbalstīt strukturālās reformas ekonomikas noturībai un izaugsmei;

- veicināt investīcijas.

Valsts parāda krīzes parādīja, ka ES un jo īpaši eirozonai ir nepieciešams ieviest ārkārtas atbalsta mehānismu, lai palīdzētu valstīm, kas sastopas ar lieliem 
ekonomiskiem triecieniem. 2012. gadā tika izveidots pastāvīgs Eiropas Stabilitātes mehānisms ar mērḳi nodrošināt finanšu palīdzības programmas grūtībās nonākušām eirozonas valstīm.

Tika veiktas arī citas finanšu sektora uzraudzības stiprināšanas reformas. Sākoties finanšu krīzei, 2008. gadā Eiropas Savienībā bija 27 finanšu sektora regulatori, kuru darbība, piemēram, banku glābšanas jomā, lielā mērā balstìjās uz nacionālo likumdošanu. Pastāvēja minimāli koordinācijas mehānismi, bet, kā parādīja krīze, tie bija nepietiekami. Tikai viens piemērs - pirms krīzes Eiropā nebija neviena instrumenta, kas l̦autu efektīvi rīkoties lielu, transnacionālu banku kraha gadījumā.

Pēc krīzes tika reformēta Eiropas Savienības finanšu sektora uzraudzība un uzlabota koordinācija starp ES un nacionālajām uzraudzības institūcijām. Abi uzraudzības līmeņi savstarpēji viens otru papildina.

2011. gadā tika izveidotas trīs Eiropas uzraudzības institūcijas: Eiropas Banku ağentūra, Eiropas Vērtspapīru un tirgu iestāde un Eiropas Apdrošināšanas un fondēto pensiju iestāde.

Šobrīd visas nacionālās uzraudzības iestādes ir pārstāvētas Eiropas uzraudzības institūcijās. To uzdevums ir strādāt pie vienota finanšu regulējuma Eiropā, risināt pārrobežu problēmas un laikus novērst sistēmisku risku veidošanos.

2014. gadā darbu sāka eirozonas banku Vienotais uzraudzības mehānisms, kurš tiešā veidā veic eirozonas dalībvalstu lielāko banku uzraudzību.

Iepriekšējās krīzes laikā finanšu tirgu uzticìbu eirozonas valstīm mazināja fakts, ka Eiropas Centrālā banka nepildīja klasiska pēdējās instances aizdevēja funkcijas. Tas lielā mērā tika atrisināts, 2012. gadā ieviešot tiešos monetāros darījumus (outright monetary transactions). Tā bija Eiropas Centrālās bankas apṇemšanās vajadzības gadījumā eirozonas valstu vērtspapīrus otrreizējos tirgos iegādāties neierobežotā daudzumā. Kad toreizējais Eiropas Centrālās bankas prezidents Mario Draghi teica savu slaveno "par katru cenu” (“whatever it takes”), viņš runāja tieši par šo apņemšanos. Lai arī tiešie monetārie darījumi līdz šim nav praksē izmantoti, pats to pastāvēšanas fakts strauji samazināja finansiālo nestabilitāti.

Visu iepriekš minēto un vēl citu īstenoto pasākumu dēl Eiropas Savienība Covid-19 krīzi sagaidīja krietni labākās starta pozīijās. ES dalībvalstīs nav finansiālās nestabilitātes, un tās var koncentrēties uz ekonomikas atbalsta pasākumiem. Nav būtisku problēmu finanšu sektorā, un var koncentrēties uz to, kā turpināt nodrošināt banku finansējumu reālajai ekonomikai. 


\section{Eiropas Savienības atbilde uz Covid-19 krīzi}

Jau sākoties pandēmijai, kḷuva skaidrs, ka Eiropas Savienībai ir nepieciešama vienota, solidaritātē balstìta atbilde uz šo krīzi. Tam bija vismaz trīs iemesli.

- Pirmkārt, krīzes pamatā ir simetrisks ārējais šoks, bet dalībvalstu spēja reageèt uz to ir atšķirīga. Mazāk izturīgas valstis krīze ir skārusi smagāk.

- Otrkārt, Eiropas Savienības dalībvalstis vieno ne tikai kopējas vērtības. Tās vieno arī kopējais tirgus bez robežām, tāpēc Eiropas valstu ekonomikas ir savstarpēji cieši saistìtas.

- Treškārt, šì krīze ir vēl viens papildu izaicinājums jau esošajiem izaicinājumiem - klimata pārmaiņas, ekonomikas zạ̦ā un digitālā transformācija, sabiedrības novecošana un sociālā nevienlīdzība. Visus šos izaicinājumus ir iespējams efektīvāk risināt, liekot kopā visu dalībvalstu ekonomisko, finansiālo un intelektuālo potenciālu.

Kopumā ES atbilde uz Covid-19 krīzi bija àtra un izlēmīga. Tika padarīti elastīgāki fiskālās uzraudzības noteikumi, aktivizējot Stabilitātes un izaugsmes pakta vispārējā izņēmuma klauzulu (general escape clause), un tika ieviests krietni elastīgāks valsts atbalsta pagaidu ietvars. Tika palielināta elastība ES strukturālo un kohēzijas fondu izmantošanai, tostarp aț̣auts 100\% ES līdzfinansējums, tādējādi ḷaujot novirzìt līdz 37 miljardiem eiro CRII ${ }^{11}$ un CRII+ instrumentu ietvaros steidzamām krīzes pārvarēšanas vajadzībām ${ }^{12}$. Eiropas Savienības institūcijas un dalïbvalstis vienojās par vēl nebijuša apjoma ekonomikas stimulēšanas pakešu pieņemšanu. Vienlaikus Eiropas Centrālā banka veica atbalsta pasākumus monetārās politikas jomā, kas ḷāva nomierināt finanšu tirgus un radìt labvēlīgus apstākḷus ekonomikas atbalsta pasākumu finansēšanai. Ar Eiropas Savienības palīdzību daudzas dalībvalstis veica aktīvus darba tirgus atbalsta pasākumus, īstenojot īstermiṇa nodarbinātības atbalsta shēmas, kas novērsa strauju bezdarba pieaugumu. Uzṇēmumiem tika nodrošināts likviditātes atbalsts, kā arī sniegts atbalsts, piešķirot algu subsīdijas un aṭ̣aujot kredītmaksājumu un nodokḷu maksājumu atlikšanu uz vēlāku laiku.

Kopumā 2020. gadā dalībvalstu veiktie fiskālā atbalsta pasākumi tiek vērtēti aptuveni $8 \%$ apmērā no ES IKP - no tiem dalībvalstu pielemtie papildu atbalsta pasākumi aptuveni $4 \%$ apmērā no IKP un jau tā vērienīgie automātiskās stabilizācijas pasākumi arī aptuveni 4\% apmērā no IKP. Dalībvalstu pielemtie papildu atbalsta pasākumi bija saistīti lielākoties ar tiešiem budžeta

\footnotetext{
11 Coronavirus Response Investment Initiative.

12 On the use of the COVID-19 specific indicators: https://cohesiondata.ec.europa.eu/stories/s/CORONA VIRUS-DASHBOARD-COHESION-POLICY-RESPONSE/4e2z-pw8r/\#4.1-on-the-use-of-the-covid-19specific-indicators-
} 
izdevumiem - 3,3\% apmērā no IKP. No tiem aptuveni $0,6 \%$ no IKP bija saistīti ar neatliekamiem veselības jomas atbalsta pasākumiem. Pārējie 2,7\% no IKP tiešie budžeta izdevumi bija saistīti ar ienākumu zuduma kompensācijām atsevišķos sektoros, kā arī īslaicīgās nodarbinātības un citām atbalsta shēmām. Papildus par 0,4\% no IKP tika piešķirti nodokḷu atvieglojumi. Vienlaikus dalïbvalstis īstenoja arī likviditātes atbalsta pasākumus aptuveni 19\% apmērā no IKP, galvenokārt valsts garantiju formā.

Īstenotie vērienīgie ekonomikas atbalsta pasākumi ḷāva 2020. gadā prognozēto ekonomikas kritumu amortizēt par apmēram 4,5 procentpunktiem. ${ }^{13}$

Tā kā Covid-19 krīze pēc būtības ir sanitārā krīze, Eiropas Savienības atbildes uz krīzi tika organizēta četros pasākumu blokos:

- atbalsts ES dalībvalstu veselības aprūpes sistēmām;

- atbalsts pētījumiem un drošu vakcīnu izstrādei;

- pārrobežu personu un kravu kustības koordinācija;

- atbalsts krīzes ekonomisko seku pārvarēšanai.

\section{Atbalsts veselības aprūpes sistēmām}

Covid-19 pandēmija parādīja, ka ne visu dalībvalstu nacionālā līmeņa gatavība un reaǵěšanas spējas ir pietiekamas. Kā piemēri tam bija pandēmijas sākumposmā nepietiekamie medicīnas aprīkojuma, piemēram, aizsargmasku, krājumi, nepietiekama slimnīcu intensīvās aprūpes gultasvietu kapacitāte, testu trūkums, zema kontaktu izsekošanas spēja utt. Vienlaikus koordinētu atbildes pasākumu īstenošanu šobrīd apgrūtina tas, ka Eiropas Savienības kompetence veselības aprūpes jomā ir ierobežota un galvenā atbildība par veselības aprūpes sistēmu organizāciju un finansēšanu gulstas uz dalībvalstīm.

Neraugoties uz ierobežotajām pilnvarām, Eiropas Komisija kopš pandēmijas sākuma ir veikusi daudz koordinācijas pasākumu. Lai palielinātu kritisko medicīnisko ierīču pieejamību, kopš 2020. gada sākuma Eiropas Komisija ir veikusi kopīgas medicīnas iepirkuma procedūras, kas l̦auj dalībvalstīm centralizētā iepirkumā saṇemt medikamentus, aizsarglīdzekḷus un medicīnisko aprīkojumu. Vienlaikus Eiropas Komisija koordinē pārrobežu ceḷojumu ierobežojumus, cīṇu pret dezinformāciju, kā arī pasākumus, kas vērsti uz kontaktu izsekošanas un genoma sekvencēšanas kapacitātes stiprināšanu. Genoma sekvencēšana ir īpaši svarīga risku, ko rada jauni vīrusa varianti, mazināšanā.

13 Commission Communication. One year since the outbreak of COVID-19: fiscal policy response. Brussels, March, 2021. 
Attiecībā uz pētījumiem drošas vakcīnas izstrādē kopš 2020. gada sākuma Eiropas Komisija ir aktīvi atbalstījusi pētniecību un inovācijas, koordinējot darbu Eiropas un arī pasaules mērogā Covid-19 vakcīnu izstrādē.

Lai nodrošinātu finansējumu nepieciešamo veselības pasākumu īstenošanā visā pasaulē, Eiropas Komisija bija viena no Koronavīrusa globālās reaǵěšanas (Coronavirus global response) iniciatīvas ierosinātājām. Šīs iniciatīvas ietvaros līdz šim ir piesaistīti 15,9 miljardi eiro, no kuriem 11,9 miljardus eiro ir nodrošinājusi Eiropas Savienība (ES dalībvalstis, Eiropas Komisija un Eiropas Investīciju banka). ${ }^{14}$

Eiropas Komisija iepriekšèju pirkuma līgumu (advance purchase agreements) veidā ir nodrošinājusi sešu daudzsološāko vakcīnu iepirkumu, ieskaitot vakcīnas no uzn̄ēmumiem BioNTech-Pfizer, Moderna, AstraZeneca, Sanofi-GSK, Janssen Pharmaceutica NV un CureVac. Kopumā ES saviem iedzīvotājiem un kaimiṇvalstīm ir apṇēmusies nodrošināt 2,6 miljardus vakcīnu devu. ${ }^{15}$

2020. gada nogalē visās Eiropas Savienības dalībvalstīs tika sākta vakcinēšanas kampaṇa, kas l̦aus pakāpeniski samazināt vīrusa izplatību.

Vienlaikus Eiropas Savienība sniedz konkrētu atbalstu vakcīnu pieejamībai ekonomiski mazāk attīstītās valstīs COVAX mehānisma ietvaros. Eiropas Savienība ir COVAX mehānisma lielākais finansiālais atbalstītājs, līdz šim nodrošinot finansējumu vairāk nekā 2,2 miljardu eiro apmērā..$^{16}$

Eiropas Savienība veselības aprūpes nozari atbalstīs arī Ekonomikas Atveseḷošanas un noturības mehānisma ietvaros. Šeit, piemēram, var minēt atbalstu slimnīcu infrastruktūras attīstībai, diagnostikas iekārtu un IT sistēmu iegādei, kā arī atbalstu medicīniskā personāla izglìtībai un apmācībai. Tas ìpaši attiecas uz tām valstīm, kuras iepriekšējo Eiropas Semestru ietvaros saṇēma valstu specifiskās rekomendācijas veselības aprūpes jomā.

\section{Turpmākie soḷi Eiropas Savienības noturības stiprināšanā iespējamo nākamo sanitāro krīžu kontekstā}

Pašreizējā situācija ir aktualizējusi jautājumu par Eiropas Savienības un tās dalībvalstu gatavību līdzīgām sanitārām krīzēm nākotnē. Zinātnieki uzskata, ka šādu zoonotiskas izcelsmes ${ }^{17}$ pandēmiju, kur vīruss pārnesas no dzīvnieka uz

\footnotetext{
14 The Coronavirus Global Response: https://global-response.europa.eu/index_en

15 Safe COVID-19 vaccines for Europeans: https://ec.europa.eu/info/live-work-travel-eu/coronavirus-response/safe-covid-19-vaccines-europeans_en

16 Turpat.

17 COVID 2025: How the pandemic is changing our world: https://news.uchicago.edu/story/covid-2025how-pandemic-changing-our-world
} 
cilvēku, riski pieaug. Tas saistīts gan ar globālo sasilšanu, gan ar planētas iedzīvotāju skaita pieaugumu un civilizācijas izplešanos, samazinot savvaḷas dzīvnieku dzīves telpu. Tādējādi pastāv risks, ka šādas pandēmijas var atkārtoties aizvien biežāk, tāpēc Eiropai jau tuvākajā nākotnē ir jābūt daudz augstākā gatavības pakāpē, lai spētu sekmīgi uz tām reagèt.

Pandēmija parādīja, ka no sistēmiskā viedokḷa ir nepieciešams daudz spēcīgāks koordinācijas mehānisms Eiropas Savienības līmenī, tāpēc 2020. gada novembrī Eiropas Komisija nāca klajā ar Eiropas Veselības savienības iniciatīvu. ${ }^{18}$ Iniciatīva paredz, piemēram, jau esošo aǵentūru - Eiropas Slimību profilakses centra un Eiropas Zāḷu aǵentūras - stiprināšanu. Vienlaikus tā paredz stiprināt medicinisko preparātu, aprīkojuma un iekārtu piegāžu koordināciju starp dalībvalstīm.

Priekšlikumu mērḳis ir uzlabot Eiropas epidemiologiskās uzraudzības, riska novērtēšanas, savlaicīgas brīdināšanas un reaǵěšanas kapacitāti. Tas ḷaus labāk aizsargāt eiropiešus pret iespējamām sanitārajām krīzēm nākotnē, vienlaikus respektējot dalībvalstu kompetenci veselības aizsardzības jomā. Tāpat tiek iezīmēti galvenie topošās Eiropas Veselības ārkārtējo situāciju reageěšanas iestādes elementi (Health Emergency Response Authority). Šì iestāde būs atbildīga par to, lai uzlabotu Eiropas Savienības līmeṇa reaǵěšanas spēju uz veselības apdraudējumiem, nodrošinot ātru nepieciešamo pasākumu koordināciju ārkārtējā situācijā veselỉbas jomā.

\section{Eiropas Savienības reakcija transporta jomā}

Pandēmijas sākumā, lai ierobežotu vīrusa izplatîbu, daudzu ES dalībvalstu pirmā reakcija bija slēgt savas iekšèjās robežas ārvalstu pilsoṇiem, kā arī apturēt starpvalstu avio un dzelzcel̦a satiksmi. Lai normalizētu situāciju, Eiropas Komisija sāka darbu pie dalībvalstu ieviesto cel̦ošanas ierobežojumu koordinēšanas un brīvas preču aprites atjaunošanas. Tika izveidota "zaļo joslu" sistēma ${ }^{19}$ un "Galileo" zaļo joslu mobilā lietotne ${ }^{20}$, kas ḷāva kravas automobiḷu vadītājiem un robežkontroles dienestiem iegūt informāciju par paredzamo gaidīšanas laiku konkrētā robežu šķērsošanas punktā.

Lai nodrošinātu koordinētu pieeju cel̦ošanas ierobežojumu noteikšanā, Eiropas Savienība ir pien̦ēmusi vienotus kritērijus, kas dalībvalstīm jāṇem vērā

18 A European Health Union: A Pharmaceutical Strategy for Europe, Brussels, November, 2020.

19 Commission's Communication. On the implementation of the Green Lanes under the Guidelines for border managementmeasures to protect health and ensure the availability of goods and essential services. Brussels, March, 2020.

20 Clarity and security through border crossings: https://galileogreenlane.eu 
pirms brīvas pārvietošanās ierobežojošu pasākumu ieviešanas, kā arī izveidojusi kopēju karti, kurā norādīti Covid-19 riska līmeṇi visos Eiropas reǵionos. Tādējādi tiek nodrošinātas vadlīnijas, lai atrastu līdzsvaru starp Eiropas Savienības pilsoṇu tiesībām uz brīvu pārvietošanos un veselības aizsardzības apsvērumbalstītiem ierobežojumiem.

Pašlaik Eiropas Savienība strādā arī pie digitālā zal̦ā sertifikāta ieviešanas. ${ }^{21}$ Šāds sertifikāts ietvertu trīs dažādus Covid-19 sertifikātu veidus, proti, vakcinācijas sertifikātu, testēšanas sertifikātu un pārslimošanas sertifikātu, un tā mērḳis ir atvieglot drošu un brīvu personu pārvietošanos pandēmijas laikā.

\section{Atbalsts dalībvalstīm pandēmijas ekonomisko seku pārvarēšanai}

Eiropas Savienības institūcijas un dalïbvalstis ḷoti īsā laikā ir vienojušās par apjomīgu ekonomiskā atbalsta pasākumu kopumu. Krīzes pārvarēšanas stratēgeijas pamatā ir mērḳis pēc iespējas saglabāt Eiropas ekonomikas kapacitāti. Krīzes periodā svarīgākais ir atbalstìt uzṇēmumus un saglabāt darba vietas, kas ir nepieciešamais nosacījums Eiropas ekonomikas kapacitātes saglabāšanā, nodrošinot ātru ekonomikas atlabšanu pèc pandēmijas.

2020. gada aprīlī tika panākta vienošanās par atbalsta paketi 540 miljardu eiro apmērā darba ņēmējiem un darba vietu saglabāšanai, uzṇēmumiem un dalïbvalstīm. ${ }^{22}$ Tika izveidoti trīs drošǐbas tīkli:

- pagaidu atbalsta mehānisms bezdarba riska mazināšanai (SURE), lai sniegtu nepieciešamo palīdzību darba n̦ēmējiem un saglabātu darba vietas. Šis 100 miljardu eiro lielais mehānisms paredz aizdevumus dalībvalstīm ar ìpaši izdevīgiem nosacījumiem, lai segtu daḷu no isstermina nodarbinātības shēmu izmaksām;

- 200 miljardu eiro lielais Eiropas Investīciju bankas izveidotais Paneiropas garantiju fonds, kas piedāvā aizdevumus ES uzņēmumiem, īpaši fokusējoties uz maziem un vidējiem uzṇēmumiem;

- Eiropas Stabilitātes mehānisma izveidotā pandēmijas krīzes atbalsta programma. Nepieciešamības gadījumā tā var nodrošināt aizdevumus visām eirozonas valstīm līdz $2 \%$ no to IKP. Kopējā pieejamā summa ir 240 miljardi eiro.

Minētā pakete koncentrējās uz ekonomikas atbalstu îstermiṇā. Domājot par ekonomikas tālāko attīstību, 2020. gada jūlijā tika panākta vienošanās par

21 Commission's Communication. A common path to safe and sustained re-opening. Brussels, March, 2021.

22 Report on the comprehensive economic policy response to the COVID-19 pandemic, Eurogroup press release, April, 2020. 
pandēmijas seku pārvarēšanai pielāgotu ES daudzgadu budžetu 2021.-2027. gadam un par Eiropas atveselıošanas plānu - NextGenerationEU. ${ }^{23}$ No finansiālā viedokḷa tā ir vēsturiski apjomīgākā Eiropas Savienības līmeņa stimula pakete 1,82 triljoni eiro. ${ }^{24}$ Turklāt Eiropas ekonomikas atjaunošanas plāns - 750 miljardi eiro - tiks finansēts, kopīgi aizņemoties līdzekḷus finanšu tirgos. Šāda pieeja Eiropas Savienības līmenī tiek îstenota pirmo reizi.

Jāpiemin arī REACT-EU programma 47,5 miljardu eiro apmērā. Šì programma balstās uz iepriekšējā daudzgadu budžeta ES fondu juridiskās bāzes, lai nodrošinātu atbalsta nepārtrauktību, līdz nākamais daudzgadu budžets un ekonomikas atjaunošanas plāns kḷūs pilnībā operacionāls. Tās mērḳis ir sniegt atbalstu krīzes seku novēršanai visvairāk cietušajos sektoros/nozarēs, sniegt atbalstu darba ņēmējiem un darba vietu saglabāšanai. REACT-EU dalībvalstīm piešķirir maksimālu elastību līdzekḷu programmēšanā starp dažādiem fondiem, 100\% ES līdzfinansējumu un retroaktīvu izmaksu attiecināmību no 2020. gada februāra.

Svarīgs ir arī Eiropas Centrālās bankas monetārās politikas atbalsts. ECB ìstenotā Pandēmijas ārkārtas iepirkuma programma 1,85 triljonu eiro apmērā palìdz nodrošināt labvēlīgus finansējuma nosacījumus eirozonas dalībvalstīm. ${ }^{25}$

NextGenerationEU ietvaros lielākais finanšu instruments būs Atvesel̨ošanas un noturības mehānisms (RRF) - 672,5 miljardi eiro. No tiem 312,5 miljardi eiro būs pieejami grantu formā, 360 miljardi eiro - aizdevumos. Tas nodrošinās finansiālu atbalstu reformām un investīcijām ar mērḳi padarīt Eiropas Savienības dalībvalstu ekonomikas noturīgākas un labāk sagatavotas nākotnei.

Šie līdzekḷi ir paredzēti gan krīzes ekonomisko un sociālo seku pārvarēšanai, gan Eiropas ekonomikas zal̦o un digitālo transformāciju atbalstam.

No Atvesel̦ošanas un noturības mehānisma finansējuma 37\% tiks novirzīti cīnai ar klimata pārmaiņām un ES dalībvalstu virzỉbai uz klimata neitralitāti, $20 \%$ ir paredzēti ekonomikas digitālās transformācijas mērķiem.

Eiropas Semestra ietvaros Eiropas Komisija ik gadu valstu ziņojumos izvērtē katras dalībvalsts strukturālās problēmas un sniedz rekomendācijas to novēršanai. Šo rekomendāciju ieviešanai ir jābūt būtiskai dalībvalstu Atveseḷošanas un noturības mehānisma plāna sastāvdaļai. Tādējādi dalībvalstīm tiek nodrošināts arī finansiāls stimuls veikt nepieciešamās strukturālās reformas ekonomikas noturības stiprināšanai.

23 Negotiation process of the 2021-2027 long-term EU budget \& NextGenerationEU: https://ec.europa.eu/ info/strategy/eu-budget/long-term-eu-budget/2021-2027/negotiations_en

24 ES daudzgadu budžeta 2021.-2027. gadam un NextGenerationEU summas ir norādītas 2018. gada cenās, ja nav norādīts citādi.

25 Pandemic emergency purchase programme (PEPP): https://www.ecb.europa.eu/mopo/implement/ pepp/html/index.en.html 


\section{3. attēls. Atveseḷošanas un noturības mehānisms}

Atvesel̦ošanas un noturības mehānisms (RRF) ir lielākais finanšu instruments Eiropas atvesel̦ošanas plāna (NextGenerationEU) ietvaros.

$\rightarrow$ Finansiālais atbalsts ar šã instrumenta palīdzïbu turpināsies līdz 2026. gadam.

Efektīva Atvesel̦ošanas un noturības mehānisma plāna īstenošana ES tautsaimniecībai var nodrošināt papildu 2\% IKP pieaugumu līdz 2024. gadam un radīt aptuveni 2 miljonus darba vietu.

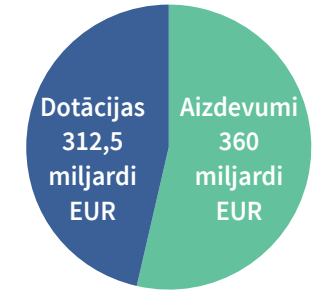

Kopējais pieejamais finansējums 672,5 miljardi EUR

\section{Eiropas pagaidu atbalsta instruments bezdarba risku mazināšanai}

2020. gada aprīlī tika panākta vienošanās par Eiropas pagaidu atbalsta instrumentu bezdarba risku mazināšanai (SURE - Support to mitigate Unemployment Risks in an Emergency), kas dalïbvalstīm sniedz atbalstu darba vietu un strādājošo ienākumu saglabāšanā. Kopējais SURE finansējums Latvijai būs 305 miljoni eiro dīkstāves pabalstu finansēšanai, no kuriem 192 miljoni eiro jau ir saņemti. ${ }^{26}$

Tomēr SURE instruments ir svarīgs arī no cita aspekta. Tas ir pirmais instruments, kura finansēšanai Eiropas Komisija veic aizņēmumus finanšu tirgos. 2021. gada janvārī Eiropas Komisija jau ceturto reizi izsolija SURE obligācijas, šoreiz 14 miljardu eiro apmērā. Investoru vidū bija vērojams liels pieprasījums pēc šìm obligācijām, kas kārtējo reizi ḷāva saṇemt ḷoti labus cenas nosacijjumus. Piemēram, 7 gadu obligācijas cena bija negatīva ar likmi mīnus 0,497\%. Savukārt 30 gadu obligāciju cena bija $0,134 \%$, kas arī ir lielisks rezultāts šāda termiṇa obligācijām. ${ }^{27}$

Šādi izsoles rezultāti ir laba ziṇa Eiropas Savienībai kā obligāciju emitentam. Tie dod pamatu uzskatīt, ka būs iespējams ne tikai sekmīgi pabeigt SURE obligāciju emisiju, bet arī tikpat veiksmīgi sākt krietni apjomīgāko NextGenerationEU aizñēmumu programmu.

2021. gada martā Eiropas Komisija publicēja pirmo SURE novērtējuma ziņojumu, kurā konstatēts, ka šā instrumenta atbalstu izmantojuši 25-30 miljoni strādājošo un 1,5-2,5 miljoni uzṇēmumu 18 ES dalībvalstīs, kuras piedalās SURE

\footnotetext{
26 SURE: Commission proposes additional €3.7 billion to six Member States to protect jobs and incomes, Press release, Marzh, 2021.

27 European Commission successfully places first EU SURE bond in 2021: https://ec.europa.eu/commission/presscorner/detail/en/IP_21_209
} 
shēmā. Pateicoties augstajam kredītreitingam, SURE ḷauj dalïbvalstīm ieekonomēt 5,8 miljardus eiro procentu maksājumos, kurus tām būtu nācies maksāt, izmantojot tradicionālos valsts parāda instrumentus. ${ }^{28}$

Domājot par pēckrīzes periodu, 2021. gada martā Eiropas Komisija nāca klajā ar Rekomendāciju efektīviem aktīviem pasākumiem nodarbinātības jomā pēc Covid-19 krīzes (EASE). ${ }^{29}$ Rekomendācijā dalībvalstīm ieteikts strādāt pie nodarbinātības politikas risinājumiem, kas ietvertu gan pagaidu, gan ilgtermiņa nodarbinātîbas pasākumus, reagéejot uz izaicinājumiem, kurus darba tirgū izraisijusi Covid-19 pandēmija. Šādām politikas paketēm jānodrošina atbilde uz iespējamu darbaspēka trūkumu noteiktās specialitātēs ekonomikas atlabšanas fāzē, vienlaikus atbalstot darba ņēmēju iespējas veiksmīgi pieskaņoties jaunajām darba tirgus prasībām, kuras izvirza ekonomikas zaḷā un digitālā transformācija.

\section{Latvijai pieejamais finansējums un tā izmantošanas iespējas ekonomiskās attīstības veicināšanai pēckrīzes periodā}

No Eiropas Savienības daudzgadu budžeta 2021.-2027. gadam un Eiropas atvesel̦ošanas plāna (NextGenerationEU) Latvija saṇems kopumā 10,5 miljardus eiro $^{30}$ grantos, un vēl indikatīvi 2,5 miljardi eiro būs pieejami aizdevumu formā. Tas veido aptuveni trešdaḷu no valsts ikgadējā IKP, kas ierindo Latviju starp lielākajiem ieguvējiem no Eiropas ekonomikas atvesel̦ošanas paketes.

\section{4. attēls. Finansiālās iespējas Latvijai}

\begin{tabular}{|l|c|}
\hline Daudzgadu finanšu ietvars 2021-2027 & 8 miljardi EUR \\
\hline Eiropas atveseḷošanas plāns (NextGenerationEU) & 2,5 miljardi EUR \\
\hline Kopējais pieejamā finansējuma apjoms & 13 miljardi EUR \\
\hline - dotācijas & 10,5 miljardi EUR \\
\hline - aizdevumi & 2,5 miljardi EUR \\
\hline
\end{tabular}

28 Commission Report. SURE: Taking Stock After Six Months. Brussels, Marzh, 2021.

29 Commission Recommendation on an effective active support to employment following the COVID-19 crisis (EASE). Brussels, March, 2021.

30 Kopējais pieejamais 10,5 miljardu eiro grantu finansējums ietver Kohēzijas politikas fondus, Atvesel̦ošanas un noturības mehānismu, Taisnīgas pārkārtošanās fondu, React-EU un Kopējās lauksaimniecības politikas maksājumus. Minētās summas ir faktiskajās cenās. 
No Eiropas Savienības daudzgadu budžeta, neskaitot NextGenerationEU, Latvija tuvākajos septiņos gados saņems vairāk nekā 8 miljardus eiro. Tas ietver piešķīrumus no strukturālajiem un kohēzijas fondiem, kopējās lauksaimniecības politikas un Taisnīgas pārkārtošanās fonda finansējumu. Jāatzīmē, ka Latvijai ir trešā augstākā atbalsta intensitāte starp Eiropas Savienības dalībvalstīm.

No NextGenerationEU, galvenokārt Atveseḷošanas un noturības mehānisma ietvaros, grantu veidā Latvijai būs pieejami ap 2,5 miljardi eiro. ${ }^{31}$

\section{Atveseḷošanas un noturības mehānisma plāns}

Pēckrīzes periodā ātra ekonomikas atkopšanās procesa nodrošināšanā būtisks būs atbalsts kopējā pieprasījuma stimulēšanai, kur liela nozīme krīzes ilgtermiņa seku pārvarēšanā būs tieši investīcijām.

Kā redzams no minēto pasākumu atspoguḷojuma, Eiropas Savienības līmenī šādām investīcijām ir radīta pietiekami spēcīga bāze. Tomēr sekmīgai un efektīvai pieejamās Eiropas Savienības finansējuma izmantošanai būs jāizstrādā kvalitatīvs Atveseḷošanas un noturības mehānisma plāns, kurā būs jāparedz investīcijas un reformas ekonomikas zaļajai un digitālajai transformācijai, ekonomikas noturības stiprināšanai un iekḷaujošas izaugsmes nodrošināšanai.

Šīm investīcijām un reformām jābūt balstītām gan valsts plānošanas dokumentos noteiktajās prioritātēs (Nacionālais attīstības plāns, nozaru plānošanas dokumenti), gan Eiropas Komisijas 2019. un 2020. gada ziņojumos par Latvijas ekonomiku noteiktajās valsts specifiskajās rekomendācijās.

Svarīgi atzīmēt tieši ar ekonomikas zaļo un digitālo transformāciju saistīto investīciju un reformu nozīmi, jo Atveseḷošanas un noturības mehānisma mērķis nav atjaunot ekonomiku pirmskrīzes stāvoklī, bet gan nodrošināt Eiropas Zaļā kursa ietvaros definēto ekonomikas konkurētspējīgo ilgtspēju (competitive sustainability).

\section{Zaḷā transformācija}

Latvija šobrīd ir starp ES līderēm attiecībā uz atjaunojamās enerğijas īpatsvaru kopējā enerǵijas patēriṇā. 2019. gadā atjaunojamās enerǵijas īpatsvars Latvijā sasniedza 41\%, kas Latviju ierindo trešajā vietā starp ES dalībvalstīm. ES

31 Atvesel̦ošanas un noturības mehānisma ietvaros Latvijai būs pieejami līdz 2,02 miljardiem eiro, no kuriem 1,65 miljardi jeb 70\% ir jau garantētā daḷa. Pārējie 30\% tiks sadalīti 2022. gadā, balstoties uz aktuālākajiem makroekonomiskajiem rādītājiem. 
kopumā atjaunojamās enerğijas īpatsvars ir sasniedzis tikai 19,7\%. ${ }^{32}$ Tomēr jāstrādā pie tā, lai Latvija spētu šo priekšrocību izmantot, ātri un efektīivi iekḷaujoties jaunajā, no oglekḷa emisijām brīvā, pasaules ekonomiskajā modelī. Zaḷās transformācijas jomā būs jāturpina nopietnas investīcijas gan transportā, gan èku siltināšanā, gan atjaunojamo energoresursu attīstībā. Latvijai būs jāturpina palielināt atjaunojamo energoresursu īpatsvaru, ko tā ir veiksmīgi darījusi siltumapgādes un elektroenerǵijas ražošanas nozarēs, bet ko nav izdevies panākt transporta nozarē. Tāpēc būs nepieciešams turpināt investīcijas videi draudzīga sabiedriskā transporta un elektromobilitātes infrastruktūras attīstībā.

Līdztekus atjaunojamo energijas resursu īpatsvara kāpināšanai nepieciešams domāt arī par enerǵijas patēriņa mazināšanu. Latvijas Nacionālajā energétikas un klimata plānā lēsts, ka kopējās investīciju vajadzības līdz 2030. gadam sasniedz 550 miljonus eiro energoefektivitātes un atjaunojamo energoresursu energijas pasākumiem siltumapgādes jomā, aptuveni 1,7 miljardus eiro ēku renovācijai, 1 miljardu eiro transporta nozares dekarbonizācijai un 130 miljonus eiro biometānam.

Vienlaikus ar nepieciešamajām investīcijām vajadzēs pilnveidot zaļo transformāciju veicinošu juridisko, finanšu un administratīvo ietvaru. Šeit var minēt pasākumus, kas saistīti ar administratīvo izmaksu samazināšanu standartizētiem èku atjaunošanas projektiem, kā arī mazākus nodokḷu atvieglojumus fosilajam kurināmajam, kas dotu papildu impulsu zaḷajiem risinājumiem energèêtikā. Tāpat jāturpina darbs pie maza mēroga zal̦o projektu veicināšanas, veidojot izdevīgu ilgtermiṇa aizdevumu mehānismu, īpaši mājsaimniecībām un mazajiem un vidējiem uzṇēmumiem.

\section{Digitālā transformācija}

Latvijai jau tagad ir laba digitālā infrastruktūra. Latvija ir starp līerēm Eiropas Savienībā, piemēram, e-pārvaldes pakalpojumu izmantošanas ziņā 83\% interneta lietotāju (salīdzinājumā ar 67\% vidēji ES) izmanto e-pārvaldes pakalpojumus. $^{33}$

Arī lielākajā dạ̣ā Latvijas pilsētu teritoriju ir ḷoti laba digitālā infrastruktūra, bet fiksētās platjoslas piekḷuves trūkumu lauku apvidos kompensē mobilā platjosla. Valstī ir labs 4G pārklājums, un Latvija ir gatava agrīnai 5G ieviešanai.

Tajā pašā laikā Latvijā joprojām nav panākts būtisks progress iedzīvotāju digitālo prasmju līmeṇa uzlabošanā, kas šobrīd ir zem ES vidējā līmeṇa. Tikai

32 Share of renewable energy in the EU up to $19.7 \%$ in 2019: https://ec.europa.eu/eurostat/web/productseurostat-news/-/ddn-20201218-1?redirect=\%2Feurostat\%2Fweb\%2Fenergy\%2Fpublications

33 Eiropas Komisijas dienestu darba dokuments 2020. gada ziņojums par Latviju. Brisele, 2020. gada februāris. 
43\% Latvijas iedzīvotāju vecumā no 16 līdz 74 gadiem ir digitālās pamatprasmes salīdzinājumā ar 58\% ES kopumā. ${ }^{34}$ Informācijas un komunikāciju tehnoloǵiju speciālisti veido nelielu darbaspēka daļu, tikai 1,7\% salīdzinājumā ar vidēji 3,9\% Eiropas Savienībā. Ieguldījumi iedzīvotāju digitālajās prasmēs ḷautu Latvijai pilnībā izmantot tās digitālās infrastruktūras piedāvātās iespējas, veicinātu digitālo risinājumu izmantošanu gan publiskajā, gan privātajā sektorā.

Ekonomikas zaḷa un digitālā transformācija jau tagad būtiski ietekmē darba tirgus situāciju. Pāreja uz resursu efektīvu, digitalizētu aprites ekonomiku, kurā pieaugošu lomu spēlēs mākslīgais intelekts un robotizācija, būtiski mainīs darba tirgū pieprasīto prasmju un specialitāšu struktūru. Zaḷā ekonomika rada lielas iespējas jaunu darba vietu radī̌anā, tomēr vienlaikus virkne specializāciju un profesiju arvien mazāk atbilst mūsdienu darba tirgus prasībām. Tuvākajos gados nopietni resursi būs jāvelta tādiem atbalsta mehānismiem, kas nodrošinātu savlaicīgu darbaspēka pārkvalifikāciju atbilstoši jaunajām darba tirgus prasībām.

\section{Iekḷaujoša izaugsme}

Svarīgs uzdevums tuvākajos gados būs nodrošināt iekḷaujošu ekonomikas izaugsmi. Covid-19 krīze negatīvi ietekmē sociālās nevienlīdzības situāciju ne tikai Latvijā, bet arī citviet Eiropā. Tomēr Latvijā joprojām ir viens no augstākajiem sociālās nevienlīdzības līmeņiem Eiropas Savienībă ${ }^{35}$, tāpēc šie jautājumi Latvijai ir īpaši aktuāli. Nabadzības riski ir izteiktāki tieši visneaizsargātāko iedzīvotāju kategorijās - starp vecāka gadagājuma cilvēkiem un cilvēkiem ar invaliditāti. Nevienlīdzība Latvijā pastāv arī attiecỉbā uz veselības aprūpes pieejamību un izglìtības kvalitāti, īpaši attiecībā uz mazākām lauku skolām. Turklāt ir lielas reg̣ionālās atšķirības ienākumu līmenī, un nabadzīgāko reǵionu iedzīvotāju ienākumu līmenis ir tikai aptuveni puse no ienākumu līmeņa Rìgā.

Lai nodrošinātu iekḷaujošu izaugsmi, pēckrīzes periodā būs jāturpina darbs pie veselības un sociālās aprūpes pieejamības uzlabošanas iedzīvotājiem, kā arī jāturpina sociālās drošības tīklu stiprināšana.

Jau pirms Covid-19, bet jo ìpaši tā izrraisītās krīzes ietekmē aizvien lielāka daļa izglìitības, sociālo un veselības pakalpojumu tiek sniegti daḷejji vai pilnībā elektroniski. Lìdz ar to pieaug arī digitālās atstumtības riski. To labi ilustrē arī pašreizējās nodarbinātības iespēju atšķirības sektoros, kuros iespējams strādāt attālināti, un tā sauktajos "kontaktsektoros". Tāpēc digitālo prasmju attīstība

\footnotetext{
34 Eiropas Komisija. Digitālās ekonomikas un sabiedrības indekss (DESI) 2020. gadā. Latvija.

35 Share of renewable energy in the EU up to $19.7 \%$ in 2019: https://ec.europa.eu/eurostat/web/productseurostat-news/-/ddn-20201218-1?redirect=\%2Feurostat $\% 2$ Fweb\%2Fenergy\%2Fpublications
} 
sociālā riska grupās būs viens no svarīgākajiem sociālās iekḷaušanas politikas uzdevumiem.

Protams, ir arī daudz citu veicamo darbu - jāturpina cīṇa ar ēnu ekonomiku, jāuzlabo publisko iepirkumu kvalitāte un efektivitāte, jāveicina konkurence vietējā tirgū un investīcijas inovācijās, digitālajā un zaḷajā infrastruktūrā, kā arī jāizveido reāls attīstības modelis reǵioniem.

Tomēr neatkarīgi no šobrīd īstenotajiem krīzes pārvarēšanas pasākumiem un pieejamā finansējuma apjoma Latvijas ekonomikas virsmērķis joprojām ir stabila ienākumu konverǵence ar ES vidējo rādītāju. Latvijas ienākumi uz vienu iedzīvotāju pēdējo piecu gadu laikā ir palielinājušies par 22\%, un tā galvenais virzìtājspēks bija produktivitātes pieaugums. Tomēr 2018. gadā tie bija tikai 69\% no ES vidējā rādītāja ${ }^{36}$, un ienākumu atšķirība ar vecajām ES dalībvalstīm joprojām ir spēcīgs emigrācijas virzìtājspēks.

\section{Produktivitāte}

Tieši produktivitātes pieaugums spēj nodrošināt ilgtspējīgu algu un iedzīvotāju ienākumu pieaugumu. Latvijas produktivitātes pieaugums ilgākā laika posmā ir bijis diezgan ievērojams gan Eiropas Savienības, gan pasaules vēsturiskajā kontekstā. Pēdējo 20 gadu laikā tās pieaugums ir sasniedzis vidēji 4\% gadā.

Salīdzinot ar tuvākajiem kaimiņiem Igauniju un Lietuvu, Latvijas produktivitātes līmenis ir par 10-15\% zemāks. Salīdzinājumā ar pārējām Baltijas valstīm Latvijas rūpniecības produktivitātes pieaugums pēdējo 5 gadu laikā ir bijis visstraujākais, bet tas joprojām ir par aptuveni 20\% mazāks nekā Igaunijā un Lietuvā. Tirgus pakalpojumu jomā Latvijas produktivitātes pieaugums ir pa vidu starp pārējām Baltijas valstīm.

Tomēr produktivitāte ir un paliek konverǵences virzītājspēks, pieauguma tempam joprojām turoties stabili virs Eiropas vidējā līmeṇa. Pēdējo 5 gadu laikā Latvijas darba ražīguma pieaugums bija vidēji 3,1\% gadā, bet ES vidējais gada pieaugums tajā pašā periodā bija tikai $1,0 \% .^{37}$

No ilgtermin,a perspektīvas raugoties, var teikt, ka Latvija ir viena no ES konvergénces līderēm. Tomēr, pieaugot labklājības līmenim, ienākumu pieaugums arvien vairāk būs atkarīgs no ieguldījumiem cilvēkkapitālā un inovācijās, kur sniegums ir bijis viduvējs.

\footnotetext{
36 Share of renewable energy in the EU up to $19.7 \%$ in 2019: https://ec.europa.eu/eurostat/web/productseurostat-news/-/ddn-20201218-1?redirect=\%2Feurostat $\% 2$ Fweb\%2Fenergy\%2Fpublications

37 Turpat.
} 
Ilgtermiņa valsts konkurētspējas nodrošināšanai ir nepieciešams būtiski kāpināt valsts un privāto pētniecībai un inovācijām paredzēto finansējumu - šobrīd 41,5\% no visām publiskajām investīcijām pētniecībā un inovācijās veido Eiropas Savienības fondi. Vienlaikus nepieciešams risināt pētniecības un inovācijas sistēmas pārvaldības sadrumstalotības problēmu, kā arī veidot uz talantu piesaisti un noturēšanu vērstu politiku zinātniskajā un tehnolog̣iskajā jomā.

\section{Secinājumi}

Krīzei sākoties, Eiropas Savienība un tās dalībvalstis varēja paļauties uz spēcìgu sociālo tirgus ekonomiku un stabilu finanšu sistēmu. Pandēmija ir parādījusi, ka krīzes pārvarēšanā svarīga loma ir ekonomikas noturībai. Stabilus ekonomikas pamatus nodrošina atbildīga fiskālā un makroekonomiskā politika, stingra finanšu sektora uzraudzība arī ekonomiskās izaugsmes fāzē, kā arī savlaicīgas reformas un investīcijas. Pašreizējo relatīvo Eiropas ekonomikas stabilitāti lielā mērā ir nodrošinājušas pēc globālās finanšu un ekonomiskās krīzes veiktās ekonomiskās pārvaldības reformas. Tomēr Covid-19 krīze ir arī skaidri parādījusi, ka darbs šajā jomā nav pabeigts. Izejot no šìs krīzes un gatavojoties nākamām iespējamām līdzīgām krīzēm, ir jāturpina uzlabot visu Eiropas Savienību veidojošo ekonomisko un sociālo struktūru elementu noturību un ilgtspēju.

Covid-19 krīze spilgti izgaismojusi līdz šim, iespējams, nepietiekami novērtēto sanitāro risku apdraudējumu globālajai ekonomikai un sabiedrībai kopumā. Vienkāršais fakts, ka "mikrobi nepazīst robežas", šobrīd liek gan pārskatìt veselības un sociālās aprūpes sistēmu nozīmi, gan meklēt veidus, kā šo sistēmu noturību stiprināt nākotnē.

Ar krīzes pārvarēšanu saistītos finanšu atbalsta mehānismus ir jāuztver arī kā unikālu iespēju veikt apsteidzošas reformas dažādās jomās. Šīs reformas ir nepieciešams priekšnosacījums, lai Eiropas Savienība un arī Latvija veiksmīgi spētu iekḷauties pasaulē notiekošajos zaļās un digitālās transformācijas procesos, kuri noteiks 21. gadsimta politisko, ekonomisko un sociālo modeli. 